\title{
微細気孔性シリカ多孔体の製造法
}

\author{
関 八千穂・小瀬三郎・児玉皓雄・門田正胤・ \\ 小倉透・谷本一美・松原一郎 \\ (大阪工業技術試験所，563 池田市緑丘 1-8-31)
}

\section{Production Method of Porous Silica Compacts Containing Submicron Pores}

\author{
Yachiho SEKI, Saburo KOSE, Teruo KODAMA, Masatane KADOTA, \\ Toru OGURA, Kazumi TANIMOTO and Ichiro MATSUBARA \\ (Government Industrial Research Institute, Osaka, 1-8-31, Midorigaoka, Ikeda-shi
}

563)

\begin{abstract}
The production technique of porous compacts of ceramics containing fine pores have been developed. The mixtures of silica ultrafine particles (pre-treated with solvents) and liquid paraffin were pressed under $300 \mathrm{~kg} / \mathrm{cm}^{2}$ and then fired at $800^{\circ}-920^{\circ} \mathrm{C}$, and the characteristics of the compacts obtained were measured. Mixtures of ultrafine silica which was pretreated by colloidal solution of silica and liquid paraffin of large quantities gave porous compacts containing fine pores. Better results were obtained when 1-18\% colloidal silica was added in pre-treatment and the firing temperature was about $850^{\circ} \mathrm{C}$. Apparent porosity was 60-80\% for the obtained compacts. The mean pore diameter was $0.04 \mu \mathrm{m}$ for the compacts fired at $800^{\circ} \mathrm{C}$, which remained virtually with increasing firing temperature, but decreased with increasing content of colloidal silica. Specific surface area was $130 \mathrm{~m}^{2} / \mathrm{g}$ for the compacts fired at $850^{\circ} \mathrm{C}$, and decreased with an increase both in temperature and content of colloidal silica, respectively.

[Received February 1, 1988; Accepted April 26, 1988]
\end{abstract}

Key-words : Forming of ultrafine powder, Porous compact, Pore size distribution, Ultrafine silica

\section{1. 緒 言}

著者らは前報1にたおて，アルミナ超微粉体に対し多 孔化に関する媒液蒸発法を適用し, 微細気孔性多孔体を 製造し，その結果を報告した。この方法は単純に言えば, セラミックス超微粉体と多量の媒液（流動パラフィン） とを混合し, 湿式加圧成形し焼成して, 媒液を蒸発させ ることにより，焼成体内に無数のサブミクロン気孔を形 成させる技術である．この多孔化技術を，アルミナ以外 のセラミックスに対し拡張するに当たって考慮すべきこ とは, セラミックス超微粉体の, 媒液中への分散, 凝集 などの挙動である. セラミックス超微粉体は, その種類, 製造法の相違，あるいは粒子生成過程の相違によって独 自の挙動をとると考えられるからである.

媒液蒸発法における重要なポイントの一つは，原料粉 体に対する前処理剤の選定であり，もう一つは成形用媒 液の選定である．前処理剤と成形用媒液をそれぞれ複数 選定できれば，それらの組み合わせは多数に達する．あ る特定の組み合わせが，与えられたセラミックスに対し 適当であれば，多孔化が実現できるであろう。本実験で は, 超微粉シリカの成形において, 成形用媒液は前報の ままとし, 前処理剂の種類を変えた. その結果, コロイ ド溶液状シリカを前処理剂に, 流動パラフィンを成形用 媒液に選定した場合, 気孔率 $78 \%$ に達する微細気孔性 シリカ多孔体の製造が可能になったので報告する.

\section{2. 実験方法}

\section{1 原料}

2.1.1 シリカ超微粉体 ${ }^{2)}$

シリカ超微粉体としては, 気相分解法により製造した シリカ（西独, デグサ アエロジル-200）を用いた。 そ の 1 次粒子の平均径は $12 \mathrm{~nm}, \mathrm{BET}$ 法による比表面積 は $200 \pm 15 \mathrm{~m}^{2} / \mathrm{g}$, シリカ含有率は $99.8 \mathrm{wt} \%$ 以上とさ れている.

\subsection{2 原料の前処理}

原料超微粉体と下記の媒液とを混合し, 乾燥してから 粉砕した.この工程を前処理と呼ぶ. 前処理用の媒液と して, 水, コロイド溶液状シリカ, エ夕ノール, n一キ サン及びベンゼンを選んだ.

コロイド溶液状シリカは, 日産化学スノーテックス “30”及び“O”[シリカ含有量は, それぞれ 30.5 , $20.5 \mathrm{wt} \%$ ，アルカリ $\left(\mathrm{Na}_{2} \mathrm{O}\right)$ 含有率の上限はそれぞれ 0.6 及び $0.04 \mathrm{wt} \%$ ，粒子径 $10 \sim 20 \mathrm{~nm}$ ] を用いた。 ス ノーテックスの含有率は, 原料超微粉体に対し, 約 1 wt \% から 65 wt \% (ドライベース) まで変化させた.

エ夕ノールなどの試薬は, 特級又は 1 級品をそのまま 用いた.

\section{2 成形用媒液}

前報では ${ }^{1)}$, アルミナ超微粉体に対し流動パラフィン 


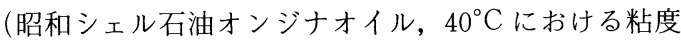
は $14 \mathrm{sSt}$ )を成形用媒液として用いて好結果を得た。こ のため，本実験においても同じものを使用した.

\section{3 成形及び焼成}

前処理を終えた所定量のシリカ超微粉体と流動パラ フィンとを混合し， $300 \mathrm{~kg} / \mathrm{cm}^{2}$ の圧力で成形した．圧 力保持は 1 分間とした. 試料の大きさは前処理剤により 変動し, $2 \times 5 \times 0.8 \sim 1.7 \mathrm{~cm}$ となった. 成形には 1 軸加

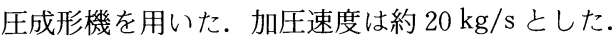

成形体はエレマ電気炉を用い大気中で焼成した。焼成 に当たり，室温から $300^{\circ} \mathrm{C}$ までの昇温速度は約 $10^{\circ} \mathrm{C} / \mathrm{h}$ とし， $300^{\circ} \mathrm{C}$ から上限温度までについては，約 $70^{\circ} \mathrm{C} / \mathrm{h}$ とした. 上限温度は $800^{\circ} \sim 1100^{\circ} \mathrm{C}$ で, 全焼成時間は一 律に 48 時間である.

\section{4 測定}

焼成を終えた試料について，焼成収縮率，見掛け気孔 率, 曲げ強さ, 気孔径分布及び比表面積を測定し, 更に $\mathrm{X}$ 線回折によって結晶相の変化を調べた. 見掛け気孔 率の測定は, 七ラミックスを対象とする通常の方法に よった。また，曲げ強さの測定は 3 点曲げ法により，支 点間距離を $30 \mathrm{~mm}$ に, 荷重速度を $0.5 \mathrm{~mm} / \mathrm{min}$ に固定 した場合に測定される, 破壊荷重をもとに計算により求 めた．測定には島津製作所オートグラフ IS 2000 を用い た. 気孔径分布と比表面積の測定には, カルロ・エルボ のポロシメーター 2000 を用いた. 水銀圧入圧力は 0.1 ～1600 気圧とし, 圧力值から気孔径への換算において 用いる水銀のパラメーターは, 接触角 $140^{\circ}$, 表面張力 $480 \mathrm{dyn} / \mathrm{cm}$ である ${ }^{3)}$. X 線回折装置はリガク RAD-2 型 を用いた．X 線源は $\mathrm{Cu} K \alpha$ 線であり, 測定条件は管球 電圧 $40 \mathrm{kV}$, 管球電流 $20 \mathrm{~mA}$, 走查速度 $2^{\circ} 2 \theta / \mathrm{min}$, 力 ウントフルスケール $2000 \mathrm{cps}$, チャート速度 20 $\mathrm{mm} / \mathrm{min}$ とした.

\section{3. 結果と考察}

\section{1 前処理剤の選択}

入手したままの，かさ高いシリカ超微粉体を加圧する とラミネーションが入りやすく, たとえラミネーション が見いだされなくても，焼成により亀裂が入りやすい. また，アルミナ超微粉体の場合 ${ }^{1}$ に倣い，原料を水で前 処理した後, 流動パラフィンを添加してから成形, 焼成 しても，成形体には亀裂が発生しやすかった。

本実験では，焼成亀裂の防止を目的に，新たな前処理 剂を選択使用した．前処理の効果は，原料のかさ密度の 増大となって現れた. 結果の一部を表 1 に示す.

上記のように処理した原料に対し, 流動パラフィンを 添加（流動パラフィンの量は，シリカ $10 \mathrm{~g} に$ 対し 5 $15 \mathrm{cc}$ とした）成形し， $850^{\circ} \mathrm{C}$ に焼成したところ，スノー テックスで前処理した場合を除き，焼結体は亀裂を生じ
あるいは変形した．この結果と表 1 との比較において， 原料のかさ密度の増大が必ずしも焼成亀裂の防止に直結 しないことが分かる．以下の実験では，スノーテックス で処理した原料を使用した。

\section{2 前処理による成形用媒液の適量の変化}

図 1 には, 前処理のために添加したスノーテックス “30” の量と，前処理済みの原料に対し添加した流動パ ラフィンの適量(添加量が少ないと,成形体にはラミネー ションが発生し, 添加量が多いと, 加圧成形中に流動パ ラフィンまたはシリカ一流動パラフィン系スラリーが金 型外に浸出する.このためトライ・アンド・エラーによ り適量を求めた）との関係を示した．図に見られるよう に，前処理の工程で添加したスノーテックスの量が増大 するに従い，流動パラフィンの量は減少した．この結果 は，スノーテックスによる前処理によって，原料超微粉 シリカの比表面積が見掛け上減少したことを意味す る ${ }^{1)}$. 添加した流動パラフィンが減少することは, グリ一 ン成形体から流動パラフィンを除去したと仮定した場合 の気孔率の減少を示唆するものであり，焼成後の気孔率 はスノーテックスの添加量の増大とともに減少すると予 想される。

Table 1. Bulk density of ultrafine silica after pretreatment with various solvents.

$\begin{array}{ll}\text { Solvents } & \text { Bulk density }\left(\mathrm{g} / \mathrm{cm}^{3}\right) \\ \text {-- } & 0.05 \% \\ \text { n-Hexan } & 0.10 \\ \text { Ethanol } & 0.10 \\ \text { Benzene } & 0.12 \\ \text { Snowtex “O” } & 0.17 \\ \text { Water } & 0.18 \\ \text { Snowtex “30" } & 0.20 \\ & ※ \text { Beforepre-treatment }\end{array}$

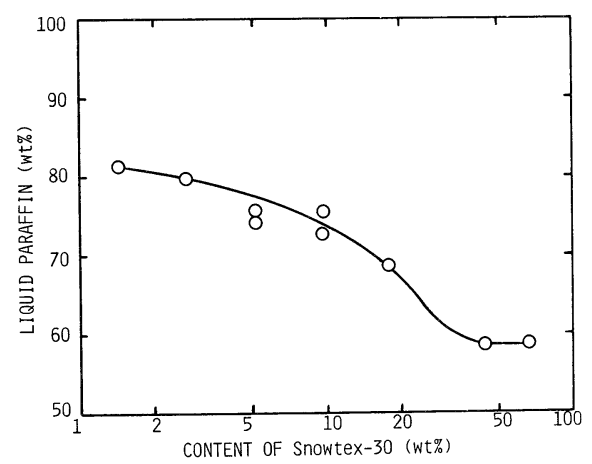

Fig. 1. Relation of the volume percentage of liquid paraffin in the green compacts to give maximal porosity and the weight percentage of the pretreating agent of Snowtex for ultrafine silica. 


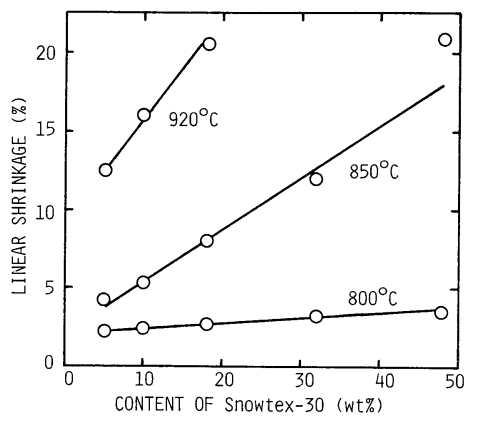

Fig. 2. Effect of added Snowtex "30" on the firing shrinkage at various temperatures.

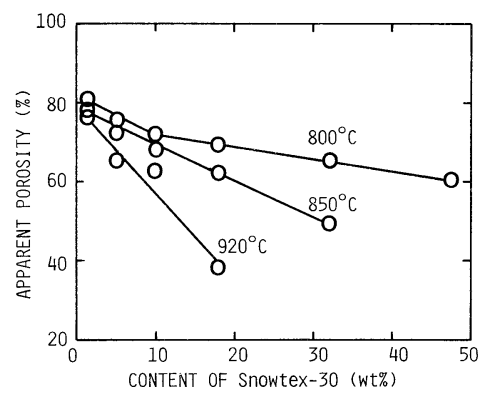

Fig. 3. Effect of added Snowtex "30" on the apparent porosity at various temperatures.

スノーテックス“O”で前処理した場合にも，上記と ほぼ同様な結果が得られた。

\section{3 スノーテックスの含有率と焼成収縮率}

図 2 に見られるように，原料の前処理のために添加し たスノーテックス“30”の量が増大するに従って，加圧 成形体の各温度における焼成収縮率は一般に増大した。

なお，収縮率が $10 \%$ を超えるかあるいは焼成温度が $950^{\circ} \mathrm{C}$ を超える場合は, 試料に亀裂が発生するか, 変形 することが多かった．スノーテックス“O”を添加した 場合も同様な傾向を示したが，同一含有率で比較して， 一般に収縮率が小さかった。

スノーテックス“30”中のシリカとスノーテックス “O”中のシリカの 1 次粒子の大きさは，共に 10 20 nm であるのに対し，主原料シリカの 1 次粒子の大きさは $12 \mathrm{~nm}$ でほぼ等しい. にもかかわらず，スノーテックス “30”はスノーテックス“ $\mathrm{O}$ ”に比較して，焼結促進の効 果が大きかった。 スノーテックス“30”と“O”との差は アルカリ $\left(\mathrm{Na}_{2} \mathrm{O}\right)$ 含有率であり, 従って収縮率の大部 分は, スノーテックス中のアルカリに起因すると考えら れる。

\section{4 スノーテックスの含有率と気孔率との関係}

図 3 にはスノーテックス “30”含有率と焼結体の気孔 率との関係を示した．罒に見られるように，各温度にお いて含有率の増加とともに，気孔率はほぼ直線的に減少
した. スノーテックス含有率の増大は, 3.2 節, 3.3 節 に述べたように，流動パラフィンの添加量を減少させ， 焼成収縮率を増大させたから，この結果は当然である。

焼成温度が $850^{\circ} \mathrm{C}$ の場合，スノーテックス“30”の含 有率 1 18 wt \% において，亀裂のない，気孔率 60～80 \%の多孔体が得られた. 同様にしてスノーテックス “O”の場合は，含有率 45 wt \% 以下において 60〜 78\% の気孔率を示す多孔体が得られた.

\section{5 スノーテックスの含有率と曲げ強さとの関係}

図 4 に見られるように，スノーテックス“30”の量が 増大するに従って，曲げ強さは増大する。ただし，焼成 温度が $800^{\circ} \mathrm{C}$ の場合は，スノーテックスの効果は著し く小さい．これは，アルカリとシリカとの反応が不十分 であることを示している. また，図5においても，スノ一 テックス“O”の含有率の増加するに従って，曲げ強さ は増大したが，図 4 における，スノーテックス“30”の 場合と比較すると， $850^{\circ} \mathrm{C}$ では，絶対値は $1 / 10$ 以下で ある。なおこの場合， $920^{\circ} \mathrm{C}$ では含有率 $30 \%$ 以上にお

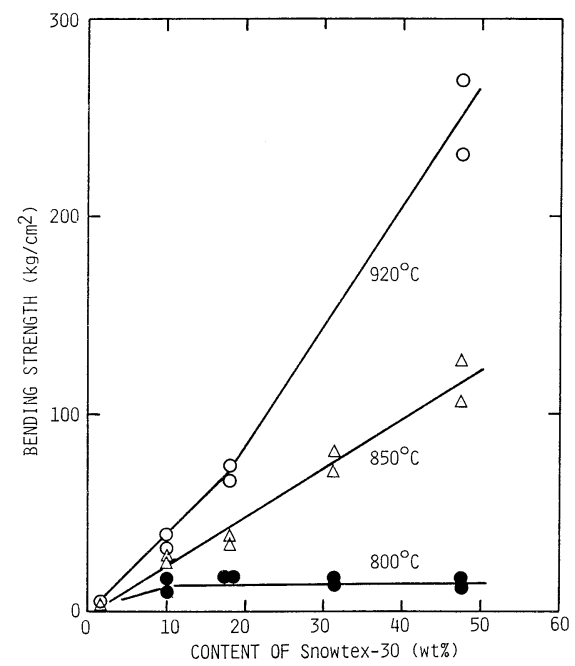

Fig. 4. Effect of added Snowtex "30" on the bending strength at various temperatures.

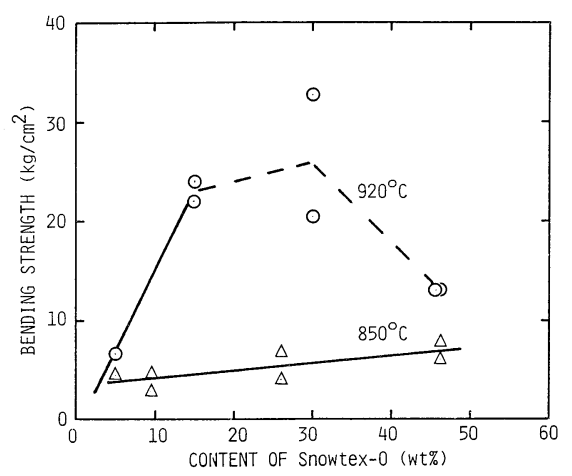

Fig. 5. Effect of added Snowtex "O" on the bending strength at various temperatures. 
いて，曲げ強さが低下したが，この原因として微細な亀 裂の存在が考えられる.

\section{6 気孔径分布 ${ }^{4)}$}

\subsection{1 気孔径分布と焼成温度との関係}

図 6 には一例として，スノーテックス “30”含有率 $2.7 \mathrm{wt} \%$, 焼成温度 $820^{\circ} \mathrm{C}$ の場合の気孔径分布を示し た. 気孔径は $12 \mu \mathrm{m}$ 以下に分布し, 約 $0.03 \mu \mathrm{m}$ にピー クが見られる。図7には $920^{\circ} \mathrm{C}$ における気孔径分布を 示した. 分布は $820^{\circ} \mathrm{C}$ の場合とほとんど変わっていな い.

気孔を円筒状と仮定したうえで，平均気孔径 ${ }^{4)}$ 算出 し, 図 8 に示した. $820^{\circ} \sim 920^{\circ} \mathrm{C}$ における平均気孔径は, 約 $0.04 \mu \mathrm{m}$ で微細であり，かつ，焼成温度によっては ほとんど変わらなかった。この結果は， $\gamma$-アルミナ超微 粉体から得られた成形体の場合の, 焼成温度の上昇に伴 う気孔径の分裂 ${ }^{1)}$ と対照的である。 $\gamma$-アルミナ成形体中 の気孔径の分裂は, 結晶相の変化の結果であったが, 本 実験のように，気孔径の分裂が見られない場合は，原料 超微粉体の結晶相にも大きな変化がないと考えられる. この点を確かめるため, X 線回折により結晶相を調べた.

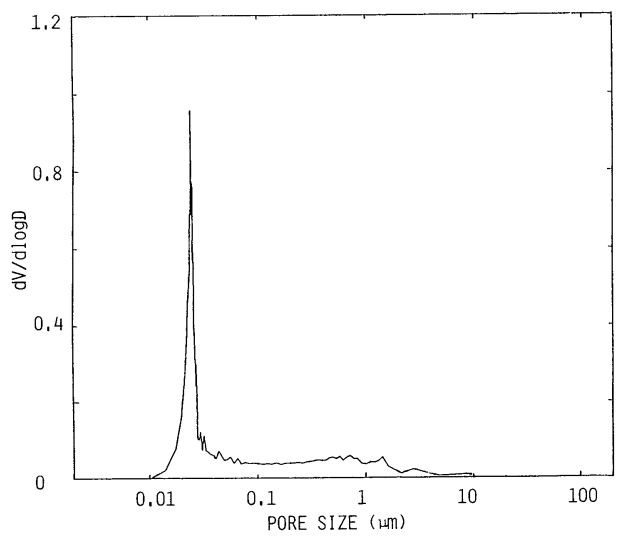

Fig. 6. Pore size distribution of the compacts containing $2.7 \mathrm{wt} \%$ of Snowtex " 30 " fired at $820^{\circ} \mathrm{C}$.

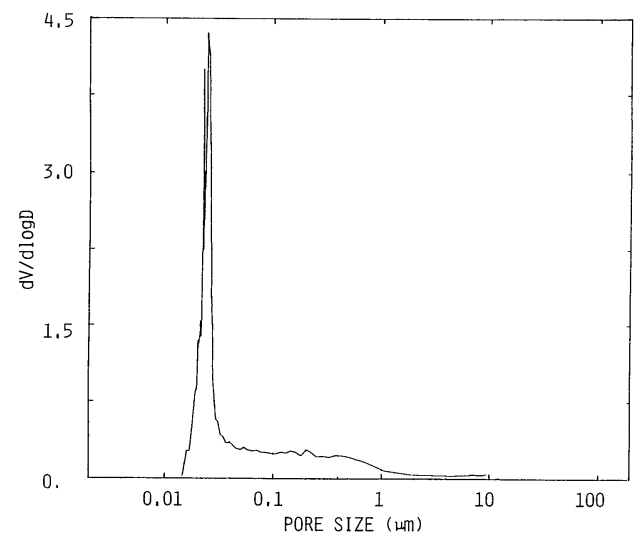

Fig. 7. Pore size distribution of the compacts containing $2.7 \mathrm{wt} \%$ of Snowtex " 30 " fired at $920^{\circ} \mathrm{C}$.
結果は図 9 に見られるように，焼成体を構成するシリカ は $800^{\circ} \sim 920^{\circ} \mathrm{C}$ 間においてアモルファスであり，X 線 図形に大きな変化は見られず, 出発原料と比較してもほ とんビ変わっていない。

\section{6 .2 気孔径分布とスノーテックス含有率との関係}

図 10 に見られるように, $850^{\circ} \mathrm{C}$ に焼成された試料の 平均気孔径はスノーテックス“30”含有率の増加するに 従い，単調にわずかに減少した。図 11 には $850^{\circ} \mathrm{C}$ に焼 成された式料を例にとり，各サイズの気孔の積算存在率 とスノーテックス “30”含有率との関係を示した. スノ一 テックス含有率が増大するにつれて，0.1 $\mu \mathrm{m}$ 以下の気

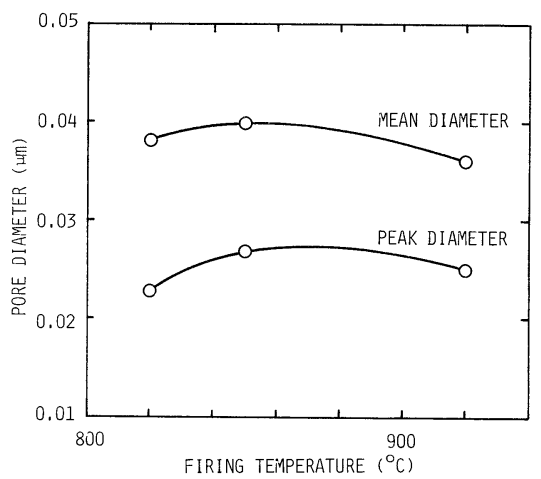

Fig. 8. Relation between firing temperature and pore diameter of the compacts.

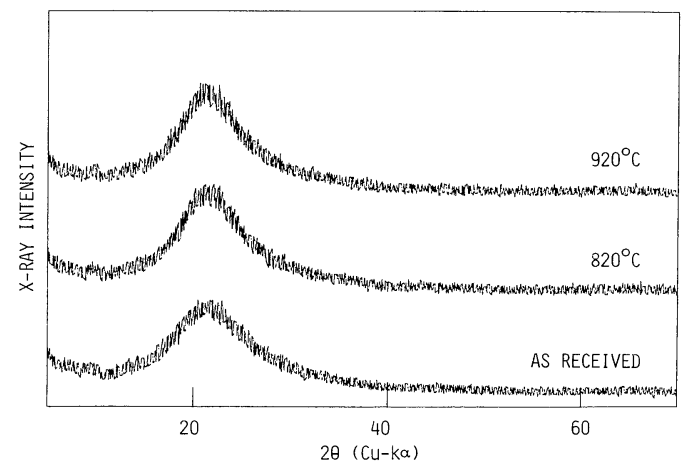

Fig. 9. X-ray diffraction patterns of the ultrafine silica as received, fired at $820^{\circ}$ and $920^{\circ} \mathrm{C}$.

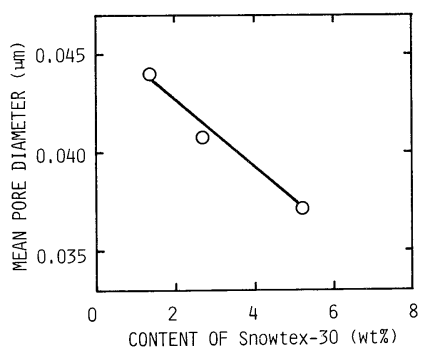

Fig. 10. Dependence of the mean pore diameter of the compacts fired at $850^{\circ} \mathrm{C}$ on the content of Snowtex "30". 


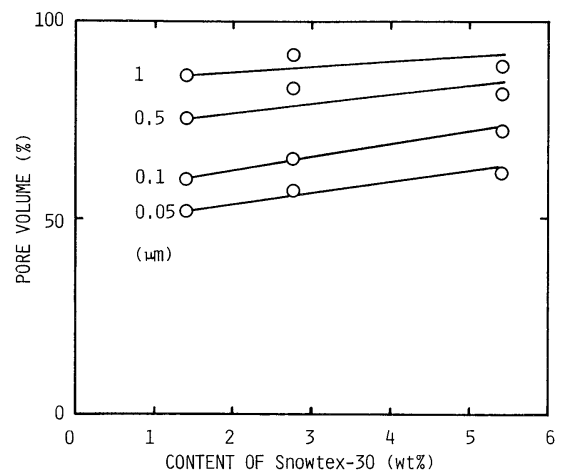

Fig. 11. Relations between content of Snowtex added to ultrafine silica and pore volumes at various pore diameters for the compacts fired at $850^{\circ} \mathrm{C}$.

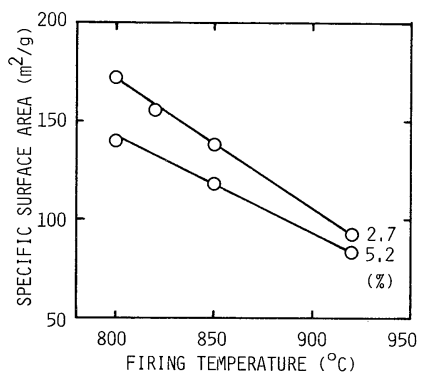

Fig. 12. Dependence of the specific surface area of the compacts on the firing temperature.

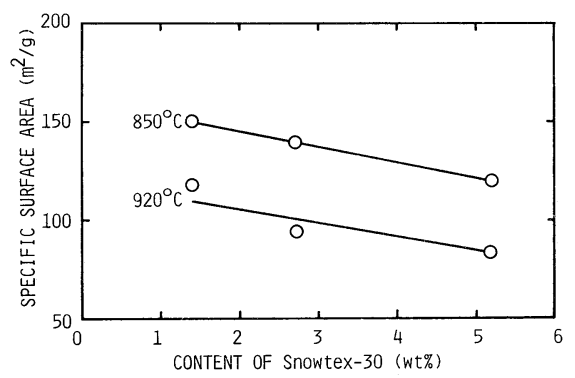

Fig. 13. Dependence of the specific surface area of the fired compacts on the content of Snowtex " 30 ".

\section{孔の存在率が増大したのが目立つ.}

\section{7 比表面積 ${ }^{4)}$}

図 12 に見られるように，焼結体の比表面積は焼成温 度の上昇するにつれて減少したが，スノ一テックス “30”含有率 $2.7 \mathrm{wt} \%$ の場合を例にとれば， $800^{\circ}$ 及び $850^{\circ} \mathrm{C}$ においてそれぞれ $170,130 \mathrm{~m}^{2} / \mathrm{g}$ を示し，比表面 積の絶対值はなお高水準にある.

図 13 には各温度における焼結体の比表面積を, スノ一 テックス “30”含有率の関数として示した. 図に見られ るように，比表面積はスノーテックス含有率が増加する に従って, 単調に減少した。

\section{4. 結 論}

シリカ超微粉体に対し, 多孔化に関する媒液蒸発法を 適用し，次の結果を得た。

（1）水，エ夕ノール， n-ヘキサン及びベンゼンを前 処理剤とし，流動パラフィンを成形用媒液とする組み合 わせでは, 亀裂のない多孔体は得られず，コロイド溶液 状シリカ（スノーテックス）を前処理剂とし, 流動パラ フィンを成形用媒液とする組み合わせにより，亀裂のな い微細気孔性多孔体が得られた。スノーテックス“30” 含有率を 1 ～18 wt \% に変動させることにより，気孔率 は 60〜80\%に調節できた。

（2）多孔体内部に形成された気孔径は，12 $12 \mathrm{~m}$ 以下 に分布し，約 $0.03 \mu \mathrm{m}$ にピークが測定された。平均気 孔径ならびにピーク気孔径は, 焼成温度の上昇によって はほとんよ゙変化しなかったが，スノーテックス含有率の 増大するに従って縮小した。

（3）多孔体の比表面積は, 焼成温度の上昇, スノ一 テックス含有率の増大するに従って減少した。ただし， 焼成温度 $850^{\circ} \mathrm{C}$ ，スノーテックス “ 30 ”含有率 2.7 wt \% においてなお $130 \mathrm{~m}^{2} / \mathrm{g}$ を示した。

（4）多孔体の焼成収縮率を支配したのは，スノ一 テックス中のアルカリであり, シリカはわずかしか関与 しなかった。

謝辞 本研究をまとめるに当たり，大阪工業技術試験所 有機機能材料部・林 和子博士並びにガラス・セラミック材料 部主任研究官・植月倫夫氏からは, 貴重な助言を頂いた。ここ に感謝の意を表します。

\section{文 献}

1) 関 八千穂, 小瀬三郎, 児玉皓雄, 門田正扸, 小倉 透, 谷本一美, 松原一郎, セラミックス論文誌, 96, 831-36 (1988).

2）加藤昭夫, 明石和夫, “化学総説 No. 48”, “超微粒子一科 学と応用”, 学会出版センター (1985) pp. 17-45.

3) H. L. Ritter and L.C. Drake, Ind. Eng. Chem. Anal., 17, 782-86 (1945).

4）近藤連一編著, “多孔材料”, 技報堂（1986）pp. 8-43. 